\title{
BELIEF AND CONTRADICTION*
}

\author{
Newton C. A. da Costa \\ University of São Paulo, Brazil \\ Steven French \\ University of Campinas, Brazil
}

Do we have inconsistent beliefs? In da Costa and French forthcoming $a$ and $b$, we argue that we do and that the simplest, most natural and most intuitive way of formalising our belief-structures is thus to adopt a paraconsistent doxastic logic.

In da Costa and French forthcoming a, we outline three possible logics of belief, of varying degrees of strength, including a paraconsistent system. It is argued that the latter is perhaps the most appropriate one for characterising certain cases where contradictory beliefs arise. One of the more prominent such cases is that of self-deception, which has generated a substantial amount of discussion in the philosophical literature and which is traditionally regarded as occurring when a person believes both that $\mathrm{p}$ and not-p. In da Costa and French forthcoming $b$, this characterisation is defended against certain recent attempts to argue that there is, in fact, no conflict and

- The authors would like to thank the Institute for Advanced Studies of the University of São Paulo and the Centre of Logic, Epistemology and History of Sciences of the University of Campinas for their support during the preparation of this paper. One of us (French) would also like to acknowledge funding received from the Brazilian National Council for Scientific and Technological Development (CNPq). 
we present a further paraconsistent doxastic system suitable for capturing the phenomenon in this form.

The purpose of this paper is to briefly indicate how these ideas 'tie in' with various others in the areas of deontic logic, akrasia and conflict in general.

We begin by recalling the pervasive nature of our belief systems and, therefore, their importance. In particular our actions in a given situation are based, at least in part, upon our beliefs regarding certain aspects of that situation, these beliefs supplying the reasons for acting the way we do (and themselves being inferred in others on the basis of their actions, in the behaviouristic construction). This is not to say that the connection between our beliefs and our actions must be a logically necessary one, in the sense that the former logically entail the latter, but only that there exists some connection between the two. ${ }^{1}$

Given this connection, weak as it may be, inconsistent beliefs about the situation we are faced with may then lead to conflict about how we should act in that situation. In particular, inconsistent moral beliefs may lead to conflicting reasons for moral or ethical action and thus to moral dilemmas of the form 'we ought to do both $p$ and not-p'. ${ }^{2}$

In this way a paraconsistent doxastic logic ties in very nicely with paraconsistent deontic ones, of the kind recently developed by da Costa and Carnielli 1987, and Puga, da Costa and Carnielli forthcoming. Such log-

1 See the collection of articles in Manuscrito 4, 1981, pp. 7-165 and, in particular, that of Marantz, ibid., pp. 159-164.

2 This is why it was important to state that the connection between belief and action may not be a logically necessary one since this position rules out moral dilemmas ab inition; see, for example, Haré 1963, who, in certain respects, follows Kant in claiming that such conflicts are simply inconceivable. Arguments to the effects that genuine cases of such dilemmas do exist may then count against such a view; Marantz, op. cit., p. 162. 
ics can accommodate those moral dilemmas which cause classical deontic systems to collapse into triviality and, moreover, accommodate them in a natural and intuitive way.

Furthermore, this account does justice to the 'facts of regret' in the sense that it does not necessarily commit us to the view that it must be possible to solve moral conflicts 'without remainder'. This is an important point which, unfortunately, cannot be discussed further here; suffice to say that the 'facts of regret' are taken to count against forms of the cognitivist view which hold that "... since it is just a question of which of the conflicting ought statements is true, and they cannot both be true, to decide correctly for one of them must be to be rid of error with respect to the other...". ${ }^{3}$ Adopting a paraconsistent deontic logic may then restore the connection between moral cognitivism and the existence of conflicting reasons for action, since with such systems we can deny one of the premises above, that the conflicting ought statements cannot both be true. ${ }^{4}$

Of course, it can always be argued that although conflicting reasons may actually exist, this does not necessarily require the adoption of a non-classical deontic logic if we refrain from rendering 'conflict' as 'contradiction'. Thus, for example, it might be claimed that in such situations we are, in fact, dealing with different kinds of reasons and therefore contradictions need not arise. Our deontic operator will then be 'indexed' in some way, in order to distinguish these different kinds. ${ }^{5}$

The problem with this approach is that, first of all, we effectively end up with as many different deontic opera-

3 Williams, 1973, p. 175.

4 Cp. Priest, $1985-86$, p. 101; for an alternative account of this questions, see Hurley, 1985-86, pp. 45-49.

5 Hurley, ibid., esp. pp. 26-27. 
tors as there are kinds of reasons, thus violating our intuitions regarding economy. Secondly, and relatedly, this tends to obscure the logical relationship between the different kinds of reasons and hence also the different kinds of obligations. ${ }^{6}$

Alternatively, reasons could be represented in terms of some kind of probability relation, according to which $p$ may be probable given a certain body of evidence $e$ and not-p probable according to a different body of evidence $\mathrm{e}^{\prime} .{ }^{7}$ However, this approach seems both clumsy and unrealistic (are our conflicts of reasons really analogous to Davidson's example of rain being probable in relation to a falling barometer and no rain being probable in relation to a red sky in the morning?) and depends upon the grounds for the conflicting reasons being distinct, which may not always be the case. Furthermore, (a related point), it has been convincingly shown, by way of actual examples, that this account does not admit cases of 'akrasia'.

Discussions of this phenomenon can be found throughout the history of philosophy, going back to Socrates and Plato and runs like a thread through more recent considerations of conflicting reasons action and rationality. ${ }^{9}$ Akrasia occurs when someone is confronted with conflicting reasons for and against doing something, say, makes an 'all-things-considered' judgement that he or she ought not to do but then goes ahead and does it anyway, for exactly the original reason in favour of doing it. If the 'all-things-considered' judgement is described as the person's preferred judgement, then a person acts akratically

- Hintikka, 1970-71; Hurley, ibid., p. 25, fn. 5, acknowledges this objection but appears to say little by way of answering it.

7 Chisholm, 1974; Davidson, 1980; Hurley, ibid., pp. 27-45.

8 Hurley, op. cit., pp. 29-45.

- For a general description, see Oksenberg Rorty, 1980. 
when he or she acts against his or her preferred judgement. Thus, akrasia arises when a person is in a state of conflict and is often regarded as demonstrating a 'weakness of will' in some sense. ${ }^{10}$

There are many important questions about akrasia which we can only mention here. For example, do cases actually exist, whether in everyday life, in psychological studies or in literature? ${ }^{11}$ Are akratic actions intentional? Oksenberg Rorty, for example, says that to qualify as akratic an action must be both voluntary and intentional ${ }^{12}$ but on the very next page ${ }^{13}$ she gives as an example a person who acts akratically despite his better judgement and against his intention. What exactly are the connections between akrasia and other kinds of moral weakness, such as sinful actions? ${ }^{14}$ Thomas Aquinas, for example, regarded akrasia as arising from self-love and therefore ultimately from original $\sin ^{15}$ but clearly not all akratic actions are morally wrong.

What connection does akrasia have with the problems of cognitivism noted above? The denial that rational regret is possible and the denial that akrasia is possible may go hand in hand since, "If it makes sense to suppose someone rationally regrets not having brought about a state of affairs, q, when he has in fact brought about $-q$, and does so for reasons, then it makes sense to suppose that he instead brings about $q$, and does so for the

10 Davidson, op. cit.; again, it is difficult to see how akrasia can be accepted by any account which holds that beliefs are logically related to actions.

11 Cp. Elster, 1980, p. 230. We might cite here the Gothic and somewhat extreme examples given in Edgar Allan Poes's "The Black Cat", 1980, pp. 191-199 and "The Imp of the Perverse", ibid., pp. 263-268.

12 Op. cit., p. 194.

13 Mid., p. 195.

14 Cp. Marantz, op. cit., p. 161.

15 Oksenberg Rorty, op. cit., p. 197. 
reason to which the regret relates, despite the different, weightier reasons favouring -q. And vice versa". ${ }^{16}$ And finally, are akratic actions irrational? Since the akrates acts against his or her preferred judgement, many people are inclined to answer 'yes'. ${ }^{17}$ On the other hand, "Far from being pathological or compulsive, the attractions of the akratic solution are that they provide a conflicted agent with an action-solution". ${ }^{18}$

These are all points which must be discussed elsewhere. What we can say here, however, is that since the source of akrasia is a conflict state embodying some form of contradiction, the phenomenon can obviously be easily accommodated within any formalisation which accepts such conflicts and contradictions at face value; that is, it finds a natural place within some kind of paraconsistent system. This would then help us to codify the relationship between akrasia and 'rational regret' noted above and, furthermore, since accusations of irrationality are often rooted in an over-reliance upon classical logics, would lead to an explication of exactly in what sense akrasia might be said to be irrational or not. ${ }^{19}$

Akratic actions are, in a strong sense, incontinent actions. In a similar way, certain beliefs might be said to be 'incontinent' also; i.e. beliefs which 'fly in the face of the evidence'. Such beliefs also arise from states of conflict and contradiction ${ }^{20}$ and are alleged to lie at the root of self-delusion and self-deception. Just as akrasia illustrates the conflict between reasons for action, so self-deception and self-delusion illustrate the conflict

16 Hurley, op. cit., p. 46.

17 Hurley, op. cit., pp. 37-40.

18 Oksenberg Rorty, op. cit., p. 194.

19 For further on contradictions and rationality see da Costa and Marconi, 1987, or Priest, op. cit..

20 For a further reference, see Elster, 1978. 
between reasons for belief. However, this masks the difference -an important one- between the latter two. With self-delusion, or so we argue in da Costa and French forthcoming $b$, the conflict results in one belief, or set of beliefs, being suppressed and the other being maintained. In cases of 'true', or 'genuine', self-deception this is not so, both conflicting sets reamining in conscious awareness.

Since the latter are typically generated by psychologically 'overwhelming' situations it seems unfair to charge them with being 'akratic' in the sense of involving a weakness of will. Such atribution seems more appropriate in cases of self-delusion, where a person is wilfully refusing to acknowledge the facts of the situation. Given this difference, with the former characterised as the prima facie, explicit, holding of contradictory beliefs, it is clear that a suitable doxastic logic for self-deception should be paraconsistent.

Which brings us round full circle!

\section{REFERENCES}

Chisholm, R. (1974): "Practical Reason and the Logic of Requirement", in S. Korner (ed.), Practical Reason. Blackwell.

da Costa, N. C. A. and W. A. Carnielli (1987): "On Paraconsistent Deontic Logic", Philosophia , 6, pp. 293-305.

da Costa, N. C. A. and S. French (forthcoming a): "The Logic of Belief", to appear in Philosophy and Phenomenological Research.

da Costa, N. C. A. and S. French (forthcoming b): "The Logic of Self-Deception".

da Costa, N. C. A. and D. Marconi (1987): "An Overview of Paraconsistent Logic in the 80's", Monografias da Sociedade Paranaense de Matematica, No. 5, julho 1987, pp. 1-39; preprint of paper to appear in Logica Nova. Akademie-Verlag.

Davidson, D. (1980): "How is Weakness of Will Possible?", in Essays on Action and Events. Oxford University Press. 
Elster, J. (1978): Logic and Society: Contradictions and Possible Worlds. Wiley and Sons.

- (1980): "Reply to Comments", Inquiry, 23, pp. 213-232.

Hare, R. M. (1963): Freedom and Reason. Oxford University Press.

Hintikka, J. (1970-71): "'Prima Facie" Obligations and Iterated Modalities", Theoria, 37, pp. 213-232.

Hurley, S. L. (1985-86): "Conflict, Akrasia ans Cognition", Proceedings of the Aristotelian Society, 86, pp. 23-49.

Marantz, H. (1981): "The Relationship Between Moral Beliefs and Action", Manuscrito, 4, pp. 159-164.

Oksenberg Rorty, A. (1980): "Akrasia and Conflict", Inquiry, 23, pp. 193-212.

Poe, E. A. (1980): Selected Tales, J. Symons (ed.). Oxford University Press.

Priest, G. (1985-86): "Contradiction, Belief and Rationality", Proceedings of the Aristotelian Society, 86, pp. 99-116.

Puga, L., N. C. A. da Costa and W. A. Carnielli (forthcoming): "Kantian and Non-Kantian Logics".

Williams, B. (1973): Problems of the Self. Cambridge University Press. [Problemas del yo (Trad. española de José M. G. Holguera), Instituto de Investigaciones Filosóficas, UNAM, México, 1986.]

Recibido: 14 marzo 1988. 


\section{RESUMEN}

Este artículo forma parte de una serie de trabajos cuya cuestión central es la relativa a la existencia de creencias contradictorias. En un artículo anterior (da Costa y French inédito a) presentamos tres sistemas de lógica doxástica, incluyendo uno paraconsistente, y argumentamos que quizás este último sea el más apropiado para caracterizar los casos en que existen creencias contradictorias. Un ejemplo de tales casos es el 'auto-engaño' [self-deception], que por lo común se considera que ocurre cuando una persona cree $\mathrm{p}$ y no-p simultáneamente. En da Costa y French inédito $\mathrm{b}$ defendemos esa caracterización contra ciertas tentativas de eliminar la contradicción, y alegamos que ésta puede ser mejor expresada por un sistema doxástico paraconsistente.

En el presente artículo insertamos nuestros argumentos anteriores en el contexto más amplio de la lógica deóntica paraconsistente, comprendiendo estudios de akrasia y de razones conflictivas para actuar. Algunos de los puntos tocados y que merecen mayor desarrollo en el futuro son:

i) La conexión entre creencias inconsistentes y conflictos en la acción. Aquí, una lógica doxástica paraconsistente se adecua muy bien a una lógica deóntica paraconsistente.

ii) La resolución de tales conflictos. Si en un conflicto moral ambos enunciados de deber [ought-statements] pueden ser verdaderos, entonces decidir en favor de uno no implica la eliminación del error con respecto al otro. Es decir, ahora podemos dar cuenta de los 'casos de arrepentimiento' [facts of regret] y restaurar las conexiones con ciertas concepciones del cognitivismo moral.

iii) La conexión entre lo expuesto y la akrasia, pues parece razonable que los casos de arrepentimiento sobre algo estén relacionados con razones para hacer aquella cosa. Esta conexión, obviamente, puede ser formalizada en un esquema paraconsistente, el cual también puede ayudarnos a explicar en qué sentido la akrasia es irrracional.

Todas esas conexiones son muy complejas y no queremos decir que podamos resolver todos los problemas filosóficos de esta área recurriendo a la lógica paraconsistente, pero estamos persuadidos de que ésta puede constituirse, por lo menos en una primera etapa, en la dirección de dicha solución.

Traducción de Gustavo ANDRÉs CAPONI UNICAMP 